\title{
PHILIP DACEY ON WHITMAN: AN INTERVIEW AND FOUR NEW POEMS
}

As THE BIBLIOGRAPHY, "The Poets Respond" (in Walt Whitman: The Measure of His Song), demonstrates, hundreds of poets have evoked, addressed, described, argued with, imitated, and parodied Walt Whitman for well over a century. Few poets, however, have more frequently, more successfully, and more imaginatively engaged Whitman than has Philip Dacey. Dacey is a professor at Minnesota State University in Marshall and the author of numerous books of poetry, including How I Escaped from the Labyrinth and Other Poems (Carnegie-Mellon University Press, 1977); The Boy under the Bed (Johns Hopkins University Press, 1981); Gerard Manley Hopkins Meets Walt Whitman in Heaven and Other Poems (Penmaen Press, 1982); The Man with Red Suspenders (Milkweed Editions, 1986), which included "Walt Whitman's Answering Service" and "Hopkins to Whitman: From the Lost Correspondence"; Night Shift at the Crucifix Factory (University of Iowa Press, 1991), which contained Dacey's first Whitman/Eakins poem, "Thomas Eakins: The Secret Whitman Sitting"; The Deathbed Playboy (Eastern Washington University Press, 1999), with a section of Whitman poems-“"Walt Whitman's Sunday With the Insane," "Harry Stafford: Whitman at Timber Creek," "The Burial" (about the death of Whitman's nephew), and "Walt Whitman Falls Asleep Over Florence Nightingale's Notes on Nursing"; and The Paramour of the Moving Air (Quarterly Review of Literature, 1999). Dacey is also the co-editor (with David Jauss) of Strong Measures: Contemporary American Poetry in Traditional Forms (Harper and Row, 1986). He is now completing a book-length sequence of poems about Thomas Eakins called The Book of Eakins, and the Walt Whitman Quarterly Review is pleased to present in this issue four of those poems exploring Eakins' relationship with Whitman. Another will soon appear in the Southern Humanities Review. Recently, I had the opportunity to ask Philip Dacey about his interest in Whitman. That interview and the four poems follow.

-Ed Folsom

Folsom: Over your career, you've continually returned to Whitman as a subject of your poetry. How would you describe your interest in him, both as a poet and as a poetic subject? 
Dacey: I think he has been an antidote to my heavily Roman Catholic education, eight years from nuns, and eight more (high school and college) from Jesuits. His paganism was what I needed for balance. Redemption of the body, which I had been taught to distrust. Earth as home rather than mere way-station preceding a greater life. He broadened my notion of miracles; not restricted to saints, they were everywhere. As subject, he has remained inexhaustible for me-I think perhaps because he was so respectfully aware of his audience and gave its members room for themselves, drew them to him but then empowered them, too, to hear their own voices.

Folsom: I'm struck by how you tend to be most fascinated by Whitman in relation to others-Hopkins, Florence Nightingale, Eakins. What draws you to these particular relationships, and why do you find them so attractive?

Dacey: Hopkins and Whitman in ways were opposites, reflecting maybe some inner drama of my own as suggested in my previous answer, so they made for an interestingly contentious pairing. With Nightingale and Whitman, however, I was struck by how much their lives overlapped with regard to wars and the dying young, although, ironically, Whitman actually did more bedside nursing than Nightingale did. In addition, she was a terrific writer: her "Cassandra," sharp and passionate, first attracted me to her. Since Whitman never met either of them, I felt obliged to bring them together in my poems. Eakins, of course, Whitman knew, so that pairing was ready-made. I'm aware that all but Eakins lived largely solitary lives, and what all four had in common was devotion to their ideals, single-minded pursuit of them. The four of them at dinner together would have made for quite an evening.

Folsom: Your Whitman poems have more historical texture than any other poems about Whitman that I know.

Dacey: Thank you. I wear out the librarians. I like to invent and extrapolate but only after a thorough investigation of the historical record. The firmer the foundation, the more confident the flights.

Folsom: Do you set out to do historical and biographical research about the events and people you write about, or does it come to you more serendipitously?

Dacey: A little serendipity followed by a lot of research: I will have an inkling of prey-material - and then ransack the books and articles in the process of landing the prey. 
Folsom: Clearly you have read a great deal about Eakins, Hopkins, Whitman, and so on. What draws you to these figures and to the latenineteenth-century milieu?

Dacey: That milieu does seem to be a kind of home to me. I think I am able to identify with that time because it's so like our own. Both 1898 and 1998 had a lot in common: the question of U. S. involvements in global conflict, of our obligations outside our boundaries; the opening of global markets, and the U.S. wanting its share; restructuring of labor and business to compete globally, with the result of hardship for many workers; new technologies uniting the globe; the rich-poor gap widening; the continuing racial division despite expectations (post-Civil War then, post-civil rights now) of harmony; and a wave of immigration causing social strife. Remarkable similarities, not to mention more obvious ones like industrial pollution and science's challenges to faith. Also there's something in the Victorian notions of earnestness and hard work and optimism and productivity that appeals to me. As the son of a factory worker, I feel the age of industry in my blood in some way; as a poet, I like to think of myself, for better or worse, as a factory-prolific, productive, keeping the machines running. Unartistic paradigm as it might be, it's mine.

Folsom: Do you have any favorite historical or biographical texts?

Dacey: One that might not be as well known as others I could name is Facing Facts: Realism in American Thought and Culture, 1850-1920, by David Shi. Both Whitman and Eakins appear in it frequently.

Folsom: I know you are now working on gathering your various Whitman poems into a book. Can you tell me something about how you are shaping this book and what aspects of Whitman you are struck by (or find yourself over the years to have been intrigued with) as you re-read and re-position these poems?

Dacey: Organizing it was a problem until I settled on the notion that, with Whitman an opera lover, I could organize the book accordingly. So the sections are: Overtures; Duo for "The Swimming Hole"; Marches; Arias; and Songs and Postludes. The aspect of Whitman that looms large for me over the years is his experience in the Civil War; my writing about that led me once to make a three-day vigil at the Vietnam Wall in Washington, D.C., and that vigil led me a few years later to make a tenday pilgrimage to Vietnam.

Folsom: When did you first read Whitman? 
Dacey: In college, but only extracurricularly. I was in the Honors Program at St. Louis University. Whitman was sort of a smuggled text in our group. And I remember an argument with another student about Whitman and Yeats, the other student saying Yeats was far superior to Whitman. That student now is a regional manager for the Denny's restaurant chain. I hope he's at least still reading Yeats.

Folsom: How often do you go back to Leaves of Grass?

Dacey: Frequently. It's is one of my permanent bedside books. Whitman feels like something of a guardian angel, if a pagan one. I saw to it that the English department's lounge at my school was named the Walt Whitman Room. An oversized poster of him I bought in San Francisco in the Sixties dominates the room. I once portrayed him in the performance of a one-act play I wrote.

\section{Folsom: Do you have favorite Whitman poems?}

Dacey: Ones that spoke earliest to me were various parts of "Song of Myself." Now I think I'd just say the whole "Song." What amazes me is how fresh it stays. I taught a five-week seminar recently in Whitman and what the undergraduates and I did for most of the time was take turns reading "Song of Myself" out loud from start to finish. Not "academic" but the right thing to do. I'm a great fan of his prose, too: "Democratic Vistas," as well as "An American Primer," his essay on the American language.

Folsom: And what do you think of Whitman as a poet? I'm curious about how the editor of Strong Measures: Contemporary American Poetry in Traditional Forms views Whitman's poetic form.

Dacey: Well, I'm very aware that the image of him as natural and spontaneous survives little scrutiny. He as you know was one of the greatest of revisers among American poets. And iambic pentameter can easily be found in lots of Whitman, inconspicuous, because of the context, but there. More generally, I have a theory that his years as a journalist account in part for his great abilities as a poet-I mean, his apprentice years were filled with his practicing of the writer's craft. I would in no way claim to be influenced as a poet by his writing; indeed, I see his work as a kind of sacred text, something inimitable, what he in fact wanted it to be seen as. I'd like to emphasize that the introduction to Strong Measures indicates the inclusive stance of Dave Jauss and me, traditional forms as some but not all of the tools in the toolbox, which should include free verse; the self-styled New Formalists (Gioia, Ma- 
son, Jarman, et al.) seem more exclusive, and Jauss and I don't like to be associated with them.

Folsom: Do you think you will continue writing about Whitman?

Dacey: I've begun what I hope becomes a book-length poem called Choreographing Whitman, which would purport to be notes a choreographer makes in the process of creating for several dancers a dance-one which crosses lines between ballet, modern, and post-modern dancebased on Whitman's life and work.

\section{WALT WHITMAN TO THOMAS EAKINS: FROM THE LOST CORRESPONDENCE}

"Whitman had a reproduction of 'The Gross Clinic' given to him by Eakins."

Henry B. Rule

I celebrate your Gross and sing your Gross,

for I hear what the talkers are talking,

what the impotent and loose in the knees

think of this painting disturbingly real

rather than politely bland out of conformity or fear-

how the flukes of the offended splash!-

yet not an inch nor a particle of an inch is vile.

I say that the soul is not more than what we see

of this young man's body, and welcome is every organ,

even the exposed buttock, the taper of his thigh

enough to confound the learning of all times.

There is no object so soft,

even as soft as these worn gray socks,

but it makes a hub for the wheeled universe.

Unscrew the locks from the clinic doors!

Unscrew the clinic doors from their jambs!

Let those who can't face, even in this painting, the removal of the diseased bone from the thigh wash the gum from their eyes!

I believe the index finger of a surgeon

is no less than the journeywork of the stars,

and the perfect incision is miracle enough to stagger

sextillions of infidels! 
All in this painting tend inward to me, and I tend outward to them.

I am of Dr. Gross and patient, the attentive students as much as the cowering mother.

Parlors and clean hands for foofoos, for me clinics and a blood-smeared knife.

Five young men bend over the patient, five assistants and all so skillful, they do not know whose hand unseen enters the circle of light and approaches the sick one to help hold open the wound or restrain the legs, they do not know whom they souse with blood.

A child visiting me asked, What is that red? and I said it is the flower of all who lived before, their sticky loyalty to us.

Or else it is a flare signalling life is serious, or maybe a bright toy

for myriads of spheres, far-sprinkled nebulae.

And now I think I could turn and live with surgeons, they are so plumb in the uprights, so haughty and electrical, they do not snivel the snivel of inaction, refusing to inflict pain to cure, they show their bold lessons to me and I accept them. Hurrah for positive science, the sharp steel knowledgeably drawn through the flesh!

I know this work of art is not a bit tame, is untranslatable.

I know it is august, nor troubles its spirit to apologize or be understood.

If I worship anything it shall be the light on the forehead of Dr. Gross-no, it shall be that forehead itself. Why should I wish to see God more than your painting? It shall be good health to you and me and everyone else who meets it head-oneveryone who has balls, that is, or heart like Mrs. Gilchrist.

I think I will do nothing for a long time but look. 


\section{CHAPTER AND VERSE IN FORT WORTH}

When the guard at the Amon Carter Museum

asked me just what I thought I was doing

talking so loud like that to myself in front

of Thomas Eakins" "The Swimming Hole"

and I said I wasn't talking to myself, I was

reading Walt Whitman's "Song of Myself"

and held up my copy of Leaves of Grass,

he told me that whatever I wanted to call it

I should take it outside, away from the other patrons, but when I further explained that in so reading and looking alternately I was really going to church in the presence of this picture and the book was my prayerbook, that I had even travelled all the way from Minnesota just for this service I was now conducting with these two sacred and related texts, one visual and one verbal, the painter and poet friends whose bodies of work overlapped in so many ways it could be said there was communion between them, he unhunched his shoulders, unknitted his eyebrows, and said, "Well, why didn't you say so in the first place, Buddy? This still after all being America, or was the last time I checked, I figure it's your right to worship as you please, and for sure it's Texas, where we're sick of running at every turn into that wall between church and state, because I never heard tell it was God we fought at the Alamo to keep out, and anyways the Amon Carter's a private institution and whatever religion you're a member of I'd judge from the way you're dressed it's not an overly organized one, so you just keep on conducting your service as you are moved to do and I'll defend you against any and all infidels as well as, since I'm a Baptist, act as your one-man congregation and supply you on cue with whatever rousing responses you need, a 'Last one in's a rotten egg,' say, or a stream of 'Amens' like water dripping from a swimmer sunning himself all natural on a rock," and with that he flashed me a ten-gallon smile, winked like some 
religio-aesthetic co-conspirator

and went on about his business of watchfully standing around or drifting from room to room, though I swear that as he directed this person and that according to their queries he now had the air of an usher steering folks to pews, a certain reverential hush surrounding him like steam around a cold, wet body in the heat, so that back at my own business I felt for the first time completely immersed in words and paint and water, a swimmer myself in media mixed by tolerance and understanding to one, a pooling of Whitman's liquid birdsong and Eakins' ooze of matter pressed to its essence, their healing baths wrung from the earth, from which I rose baptized into the wonderful ways, as unpredictable as grace, of Ft. Worth.

\section{HEADWATERS}

This is our body.

Gary Snyder, “The Bath"

It wasn't until I'd been standing in front of Thomas Eakins" "The Swimming Hole," Whitman in hand and open to twenty-eight young men bathing by the shore, that I recalled the photograph my wife took of me and my two sons also bathing decades ago in the claw-footed tub:

for the first time those three great drops of water, those dots, connected, and I realized they were all one, murky and sacred, and that to have such a thought was to dive in head first.

In the photo, I hold the infant Austin, lifting him chalice-like under his arms and face forward to the camera, his genitals visible, mine hidden behind him, as four-year-old Emmett's are behind me. We're all glisten and grin, as clean as a whistle from an admiring wife and mother, 
or silent whistle from the twenty-ninth bather richly dressed behind the blinds of the window.

The photo sáys, Here we are, World, we three Dacey males, unembarrassed in our nakedness, flaunting it even-performing a perfect sit-down strut in a tub-and sousing each other with spray as if I meant to wash away the fine grit of my sixteen years of education by nuns and priests, Incarnate Word and Jesuit, the body the enemy, now cleansing myself back to paganism until I become that one I was told to pray for as a child, to whom I even sent pennies.

So when I connected the dots what I saw were three heathen tableaux, each a morph of the others, superimposition, sluice back down to some pre-Christian era, Arcadia even where a voice booms out from behind a cloud: our local god Whitman's laying down his usual law, "Undrape! You are not guilty to me," and we all splash togetherthe tub suddenly enlarged but still crowdedto form a society of - count us - thirty-seven males, if not pre-Eve then at least extra-Eve and moreoversee there, that's Harry, Eakins' Irish setter in the water with his master-post-dog.

Of course, that local god-local to New Jerseymay have had more or other than fatherly feelings for the bathers he dreamed into existence-wasn't he, perforce, the lady, who dreamed herself the water as it passed in little streams all over their bodies?but Eakins gazes up from his wide-angled, wet corner at those destined, with their fellow students, to be all he ever knew of sons, he whose father's hand from underneath bore him steady up through all seas son-rocking, near son-swamping, and who would naturally, so fathered, father further.

But even if the two friends swam in private each according to his own different strokes, poet and painter would have agreed the stone jetty, foundation of a razed mill, appears altar-like, these bodies ranged on it sacrifices to time, 
objects of a faith, Hoc est corpus meum, in which I am well pleased, the students herein their own day's lesson, removed for purposes of study and celebration to a kind of heaven, gold-framed, in the name of the diver and of the knife-like entry and of the held breath before bursting through to air again.

Later, my own bursting through the museum doors to Fort Worth air again meant baking in noon, though I cooled to feel an amniotic slosh and slap between my ears, permanent pool, water of words, oil paint, and silver nitrate, for ducking under out of any heat.

Amon Carter Museum, Fort Worth, 1997

\section{TALCOTT WILLIAMS}

"Whitman.-And Eakins—what of Tom Eakins?"

Horace Traubel, "Round Table With Walt Whitman"

At the 72nd birthday party of Walt Whitmanin weak moments, the guardians of the gate for the Contemporary Club let in journalists like me to mingle with the brighter lightsthe poet almost had to be carried downstairs to join the thirty of us gathered around the table spread in the parlor of his Camden home, though surely the bigger lift came from the champagne flowing freely for the occasion: I think he kept up a steady string of toasts to this person and that, there or not there, to extend his sipping. And tributes to Walt flowed, too, from both those present as well as letters read aloud.

Lively as the whole affair was, however, I liked it best when Walt called out for Eakins, whom I'd known for ten years, even modelled for, the lounger on the jetty balancing his own figure, neck-deep in water and swimming, 
the two of us occupying the lower, acute angles of the triangle upon which he based the painting so few have seen-thanks to the cowardly Coates, who would not accept what he'd commissioned, lest it offend-but which I'm convinced will carry my friend's reputation far into the future.

The poet, learning Eakins was indeed one of the company, insisted he stand and make a speech.

I'd been enjoying watching Tom enjoying watching everyone else, his silence among so many wordsmiths as predictable as his pleasure among so many self-displaying brains. Tom liked talk that charged the air and lit up faces in its vicinity, but didn't care to add his own less showy but always considered, pointed voice; he liked to say he said what he had to say in his work. If Whitman's slipped under our bootsoles now, I guess Tom's just (just?) hanging on a wall. That day, he was wearing a seaman's jacket and coarse, loose trousers, not so much as tribute to Whitman the poet of the working man as simply what Eakins tended to wear most days, opposed to any airs, in dress or otherwise.

When Tom parried that he wasn't a speaker, Whitman's rejoinder hit the mark, especially since he added with his hand a flourish that seemed to mimic a brush delivering a load of paint onto canvas, a rough stroke of the sort you'd imagine Whitman making if he were a painter and meant here, I felt, to give Tom heart: "Then the more likely you are to say something of value."

So Eakins stood and painted, in miniature, as he spoke: "A few years ago, I made an oil portrait of Mr. Whitman, beginning in my usual way but soon learned it wouldn't do, that rules and tradition had to be thrown aside, for, before all else, Whitman required treatment like a man, whatever became of what commonly are called the principles of art." Hearing such words, this journalist, ready to sniff true from false, wondered: the compliment 
that lowered art to raise Walt was pretty, but didn't Whitman constantly revise his poems and Eakins trust nothing in his paintings to chance, fortunate falls, always calculating close?

Because even journalists, at times, have manners, I said nothing. Anyway, the idea of these two men as natural forces was a fine sauce-food followed the toasting - to lavish on the truth. As we waited for at least a touch more from the painter, he sat unceremoniously down, his speechifying, albeit brief, completely done.

The speech's brevity was out of all proportion to its effect as part of the pas de deux these great American artists treated us to. Recalling, with a twinge, what my friends called me, Talk-a-Lot Williams, who could be counted on to fill up space of any sort with words, I knew I had witnessed a pairing to outlast the occasion, ink- and paint-stained hands solidly linked across the Delaware, a modern span from Philadelphia to Camden.

Suddenly I saw another triangle I shared with Eakins, the third corner this time no standing swimmer but Whitman in his chair, and just as dominant as any youth.

For each angle, a contrast: my hot air,

Tom's silences; Walt's wide-spreading poetry, my narrow column-inches easy for toppling; and, best, Tom's gifts to the eye, Walt's to the ear. Leaving the dinner, I wanted us three to add up: 180 degrees of American dream, even if only isosceles, my angle not being equal to the other two.

Needing, of course, my editors faith in me, I wrote the story minus the geometry. 